\title{
RELATIONSHIP BETWEEN THE SECRETION OF THE CORPUS LUTEUM AND THE LENGTH OF THE FOLLICULAR PHASE OF THE OVARIAN CYCLE
}

\author{
D. T. BAIRD, T. G. BAKER, K. P. MaNATTY AND P. NEAL \\ M.R.C. Unit of Reproductive Biology and \\ Department of Obstetrics and Gynaecology, University of Edinburgh, \\ 39 Chalmers Street, Edinburgh
}

\begin{abstract}
Summary. The variation in the length of the follicular phase in many mammals may be related to the cellular origin of oestradiol secreted during the luteal phase. In all species the time taken for a small developing follicle (4-5 layers of granulosa cells) to mature to a preovulatory follicle may be the same as that which has been found experimentally in the mouse (10-17 days). In animals such as the sheep, in which there is no source of oestradiol other than the Graafian follicle, follicular development proceeds unimpaired throughout the luteal phase, and the 'follicular phase' which involves only the final stages of maturation of the Graafian follicle is relatively short. In primates, however, in which there is an extrafollicular source of oestrogen from the CL, the secretion of gonadotrophins is suppressed during each luteal phase to a level too low to initiate and maintain follicular development. At the end of each luteal phase and the beginning of the subsequent follicular phase, therefore, it is necessary to initiate the growth of a new crop of small follicles. The time taken for these follicles to develop into preovulatory follicles determines the length of the follicular phase.
\end{abstract}

A striking difference between the ovarian cycle in many primates and that in other species of mammals is the length of the follicular phase. Old World primates have a follicular phase of about 14 days, which is approximately the time taken for that part of follicular development which is gonadotrophin dependent. The follicular phase in the cow, sheep, pig, goat and horse is much shorter than in primates and ranges from 3 days in the sheep to 7 days in the pig (Cole \& Cupps, 1969). Follicular growth in these species is either much quicker than in primates, or, more likely the follicular phase represents only the last few steps of maturation. If the latter is true it implies that the secretion of FSH and LH during the luteal phase must be sufficient to allow follicular development to proceed before regression of the CL occurs.

Most of the available evidence indicates that the final stages of follicular development from four layers of granulosa cells to mature Graafian follicles are controlled by the levels of circulating FSH and LH (Mauleon, 1969). It is difficult, however, to determine the dynamics of this process from static 
estimates of the numbers of follicles at each stage (Block, 1951; Koering, 1969; Brand \& de Jong, 1973). By labelling the growing follicles with tritiated thymidine it has been shown in the mouse that the early developing follicle takes 10-17 days to mature to the preovulatory stage (Pedersen, 1970).

In this paper we will attempt to relate the differences in the length of the follicular phase of the sheep and the human to differences in the secretory activity of the CL.

\section{FOLLICULAR GROWTH}

In most mammals, follicular growth occurs as a continuous process throughout prepubertal and adult life (Pedersen, 1972). In the ewe (Brand \& de Jong, 1973) and cow (Rajakoski, 1960), healthy follicles of up to $5 \mathrm{~mm}$ diameter are found in the ovaries throughout the luteal phase of the cycle. These follicles secrete oestradiol in vivo (Scaramuzzi et al., 1970), although the majority eventually become atretic (Smeaton \& Robertson, 1971). If the CL is surgically enucleated at any time during the luteal phase, at least one follicle proceeds to grow and a fresh ovulation occurs within 3 days (Mallampati \& Casida, 1970). The exact relationship between gonadotrophins and follicular development in sheep is not clear, although it has been shown that follicular growth can be stimulated by exogenous gonadotrophins (Robinson, 1959). With the exception of the periovulatory period, the concentrations of FSH and LH in the blood remain fairly constant throughout the oestrous cycle (L'Hermite et al., 1972).

Follicular growth in women starts when the secretion of FSH and LH rises during luteal regression at the end of each menstrual cycle (Ross et al., 1970). At this stage, FSH but not LH enters the follicular fluid of small follicles (diameter $<6 \mathrm{~mm}$ : McNatty et al., 1975). The developing follicle is the major source of oestrogen by Day 7 because the concentration of oestradiol in ovarian venous plasma draining the ovary containing the developing follicle is higher than that on the other side (Baird \& Fraser, 1974). The rise in the secretion of oestradiol inhibits that of FSH by negative feedback and the concentration of peripheral plasma FSH falls progressively (Midgley \& Jaffe, 1968). The growth of the Graafian follicle is maintained, however, by: (a) the high concentration of oestradiol within the follicle which probably sensitizes the cells to both FSH and LH (Goldenberg et al., 1972); and (b) the concentration of FSH in those follicles in which the concentration of oestradiol exceeds $1 \mu \mathrm{g} / \mathrm{ml}$ remains relatively high (McNatty et al., 1975). Thus the follicle which is secreting oestradiol stimulates its own growth while at the same time (by its effect on the hypothalamic-hypophysial axis) inhibiting further growth of other developing follicles, which consequently become atretic.

During the luteal phase of the cycle in women there is a marked change in follicular activity (Block, 1951). Early in the luteal phase there is a relative increase in the number of developing antral follicles, possibly in response to the mid-cycle peak of LH and FSH. However, in the mid- and late luteal phase this 'wave' of growth is arrested and virtually all follicles with a diameter $>5 \mathrm{~mm}$ undergo degeneration. The concentration of oestradiol in follicular fluid and ovarian venous blood remains low (Baird \& Fraser, 1975), indicating that follicles in the luteal phase do not secrete appreciable amounts of oestrogen. It 
may be that this low level of follicular activity is due to the lack of gonadotrophic stimulation since the concentrations of FSH and LH in plasma are lower during the mid- to late luteal phase than at any other time during the menstrual cycle (Midgley \& Jaffe, 1968). Similar changes in follicular activity (Koering, 1969) and secretion of gonadotrophins (Niswender \& Spies, 1973) occur in the luteal phase of the rhesus monkey.

If these differences in follicular activity during the luteal phase of the cycle in sheep and women are related to different levels of gonadotrophin, it is likely that the secretion of ovarian steroids will also be different in the two species.

SOURCE OF STEROIDS DURING THE LUTEAL PHASE OF THE GYGLE

The human CL is almost unique amongst mammals in synthesizing and secreting androgens and oestrogens as well as progestagens (Savard et al., 1965; Mikhail, 1970). The secretion of oestradiol by the CL is responsible for the rise during the second half of the menstrual cycle in the production rate of oestrogen, which reaches a peak about 8 days after ovulation when the mature CL is secreting large amounts of progesterone (Baird \& Fraser, 1974; Brown, 1971).

The luteal cells responsible for the synthesis of these steroids are difficult to identify. Isolated thecal and granulosa cells of the Graafian follicle, which both contribute significantly to the CL in women (Corner, 1956) (PI. 2, Figs 5 and 6 ), have the capacity to synthesize oestradiol as well as progesterone in vitro (Ryan \& Smith, 1965). From the temporal relationships of the histological, histochemical and endocrine changes, it appears likely that in the follicle oestradiol is made by the thecal cells and progesterone by the membrana granulosa (Short, 1964; YoungLai \& Short, 1970). The thecal cells appear histologically most active at the time of peak secretion of oestradiol (P1. 1, Figs 1 and 2) but have become much smaller by the time of ovulation (Pl. 1, Figs 3 and 4) when the secretion of oestradiol has fallen dramatically (Baird \& Fraser, 1974). The granulosa cells show no histological signs of secretory activity until immediately before ovulation when changes consistent with early luteinization appear (Hertig, 1967), i.e. the cytoplasm enlarges and becomes granular in appearance (Pl. 1, Fig. 2) and there is an increase in the extent of smooth endoplasmic reticulum (Crisp et al., 1970; Delforge et al., 1972). At this time and coincidental with the LH peak, the concentration of progesterone rises in peripheral plasma (Johansson \& Wide, 1969; Yussman \& Taymor, 1970), in ovarian venous plasma (De Jong et al., 1974) and particularly in follicular fluid (Sanyal et al., 1974; McNatty et al., 1975). The presence of $3 \beta$-ol steroid dehydrogenase can be demonstrated histochemically in the granulosa cells of preovulatory follicles (Friedrich et al., 1974). Taken together these data strongly suggest that, before ovulation, oestradiol and progesterone originate from the thecal and granulosa cells respectively, and it is possible that thecal lutein cells contribute to the production of oestradiol by the mature CL.

Although the evidence that the GL of other Old World primates secrete oestrogen is less conclusive, the concentration of oestrogens in plasma or their excretion in urine rises to a second peak in the luteal phase in the rhesus monkey (Knobil, 1974), baboon (Stevens et al., 1970), chimpanzee (Graham et al., 1972) and orang utan (Collins et al., 1973). 
In contrast, the CL of the sheep does not have the capacity to synthesize oestrogen when incubated in vitro (Kaltenbach et al., 1967) and in vivo only progesterone and 20 $\alpha$-dihydroprogesterone are secreted (Short, 1964; Baird et al., 1973). Although the secretion of oestradiol (and androstenedione) continues throughout the luteal phase both steroids originate from the Graafian follicles (Baird et al., 1973). No difference has been found in the secretion of oestradiol from the ovary containing the $\mathrm{CL}$ and that from the contralateral ovary (D. T. Baird \& R. J. Scaramuzzi; unpublished results). The theca interna becomes much less prominent after ovulation and although thecal lutein cells are said to contribute to the CL of the ewe they are barely identifiable in the fully formed CL (Hansel et al., 1973). The cow GL has a similar structure and is unable to synthesize oestrogens (Savard et al., 1965).

In summary, although oestradiol and progesterone are secreted throughout the luteal phase in both sheep and women, the source of the oestrogen is different. In sheep oestradiol originates exclusively from the Graafian follicles and the CL secretes only progesterone; in women the follicles contribute little to the total ovarian secretion of oestradiol, over $90 \%$ of which originates from the CL.

\section{FEEDBACK OF OVARIAN STEROIDS}

Oestradiol and progesterone have established roles in the control of gonadotrophin secretion (Knobil, 1974). The effect of oestrogen on gonadotrophin secretion is critically dependent on dose. Thus the basal secretion of FSH is particularly sensitive to the negative feedback action of oestradiol and is suppressed by doses which have no effect on (or actually stimulate) the release of $\mathrm{LH}$ (Tsai \& Yen, 1971; Cargille et al., 1973). This effect of dose is presumably responsible for the rise in the concentration of $\mathrm{LH}$ in the mid-follicular phase of the cycle which occurs at a time when the secretion of oestrogen is increasing and the concentration of FSH is falling (Midgley \& Jaffe, 1968). When the secretion of oestradiol reaches between 200 and $300 \mu \mathrm{g} /$ day, the cyclic centre in the hypothalamus is stimulated by positive feedback and the mid-cycle release of LH (and FSH) occurs. In women, administration of larger amounts of

\section{EXPLANATION OF PLATES}

The follicles and CL were removed from women on various days of the cycle (Day 1 $=$ first day of menstruation). All sections were fixed in Bouin, cut at $6 \mu \mathrm{m}$ and stained with haematoxylin and eosin. $\mathrm{OE} \mathbf{E}_{2}=$ oestradiol; $\mathbf{P}_{4}=$ progesterone; $\mathrm{FSH}$ is expressed in terms of M.R.C. FSH 68/39; LH is expressed in terms of M.R.C. LH 68/40.

PLATE 1

Frg. 1. Graafian follicle, $12 \mathrm{~mm}$ in diameter, removed from a woman on Day 11. Mean cycle length $=28$ days. Endometrium: mid- to late proliferative. Hormone concentrations in follicular fluid: $\mathrm{OE}_{2}=320 \mathrm{ng} / \mathrm{ml}, \mathrm{P}_{4}=36 \mathrm{ng} / \mathrm{ml}, \mathrm{FSH}=3.8 \mathrm{mU} / \mathrm{ml}, \mathrm{LH}=$ $<0.8 \mathrm{mU} / \mathrm{ml}$; and in peripheral plasma OE $2=0.154 \mathrm{ng} / \mathrm{ml}, \mathrm{FSH}=5.1 \mathrm{mU} / \mathrm{ml}, \mathrm{LH}=$ $14.0 \mathrm{mU} / \mathrm{ml}$. The antrum is at the bottom right. The cytoplasm of the thecal cells $(T)$ is abundant and more lightly stained than that of the granulosa cells $(G) . \times 230$.

FIG. 2. Graafian follicle, $18 \mathrm{~mm}$ in diameter, removed from a woman on Day 15. Mean cycle length $=28$ days. Endometrium: late proliferative. Hormone concentrations in follicular fluid: $\mathrm{OE}_{2}=3500 \mathrm{ng} / \mathrm{ml}, \mathrm{P}_{4}=2460 \mathrm{ng} / \mathrm{ml}, \mathrm{FSH}=6.1 \mathrm{mU} / \mathrm{ml}, \mathrm{LH}=5.6 \mathrm{mU} /$ $\mathrm{ml}$; in peripheral plasma: $\mathrm{OE}_{2}=0.126 \mathrm{ng} / \mathrm{ml}, P_{4}=0.2 \mathrm{ng} / \mathrm{ml}, \mathrm{FSH}=10.5 \mathrm{mU} / \mathrm{ml}$, $\mathrm{LH}=35.2 \mathrm{mU} / \mathrm{ml}$. The antrum is at the bottom right. The thecal cells $(\mathrm{T})$ resemble those in Fig. 1, but the basal granulosa cells (G) are elongated. $\times 230$." 

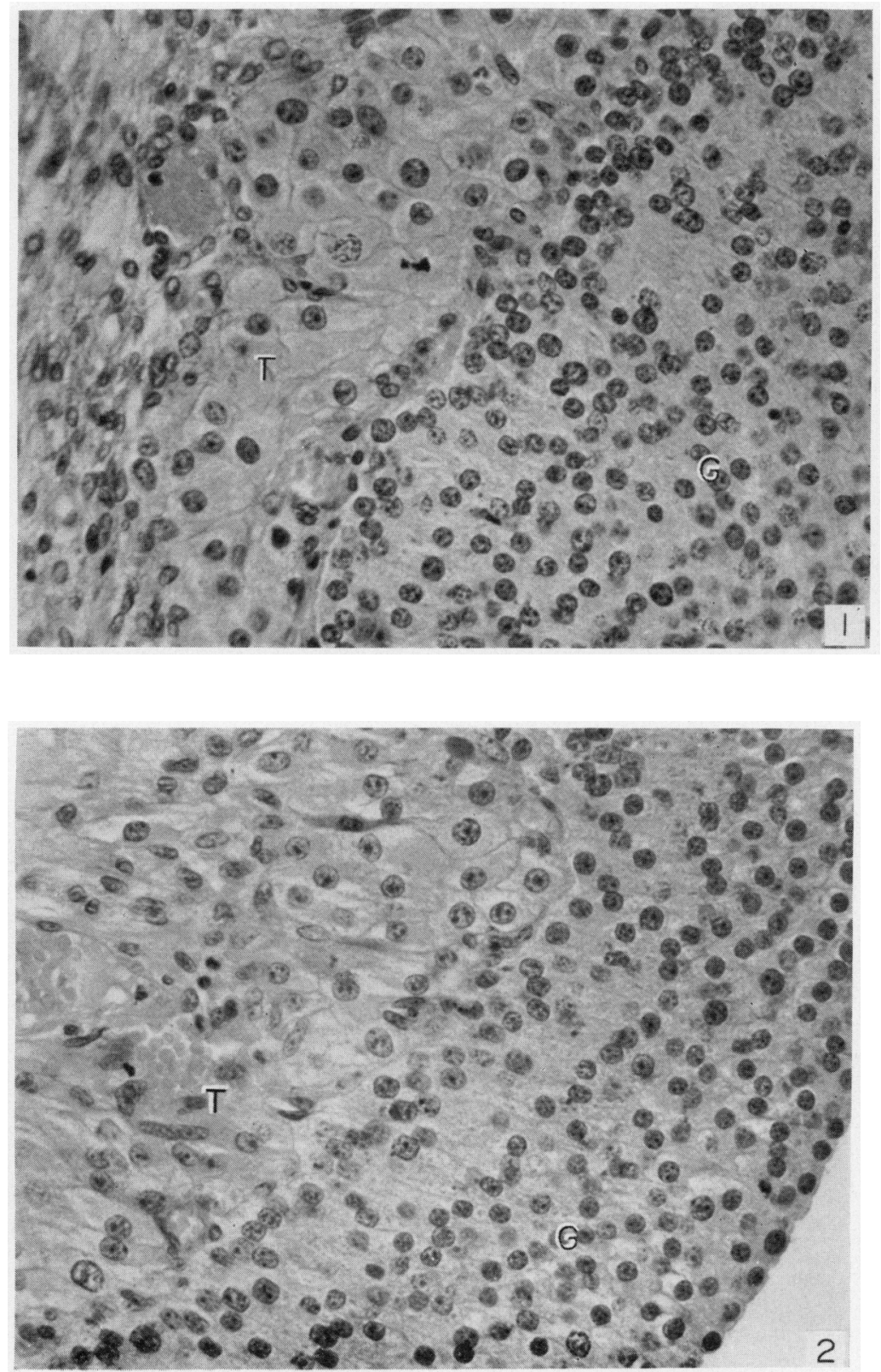

(Facing p. 614) 
PLATI:
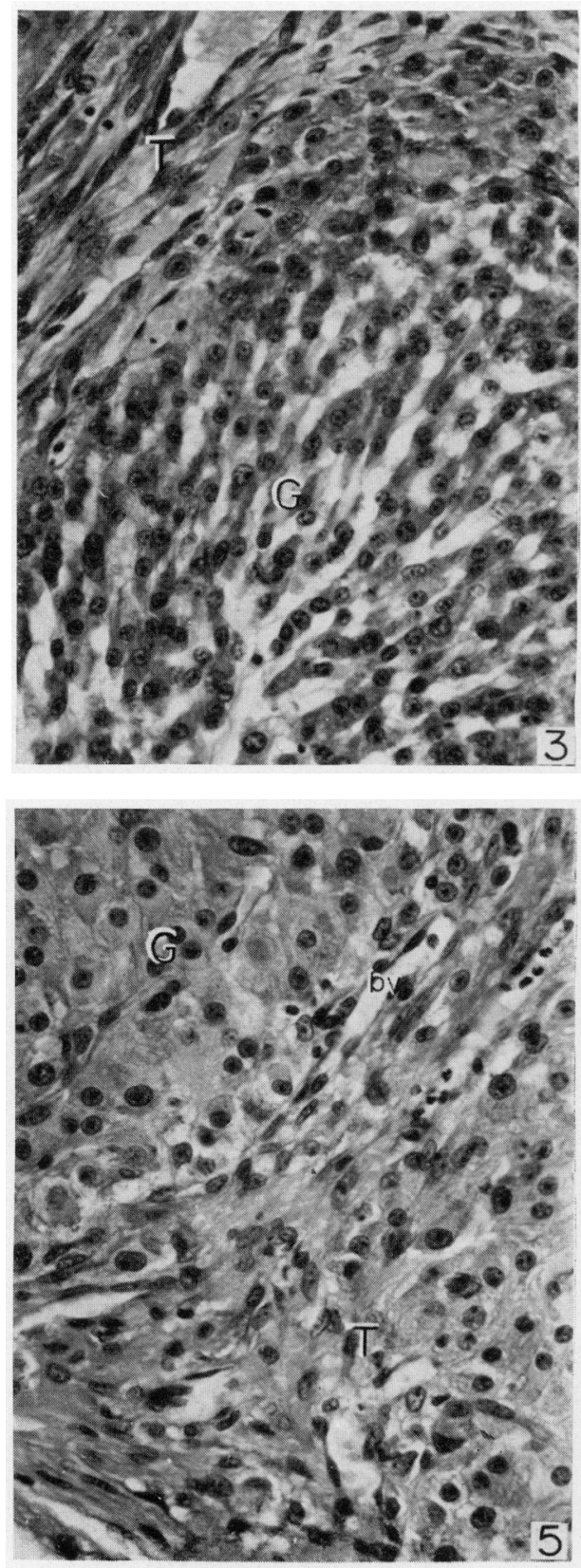
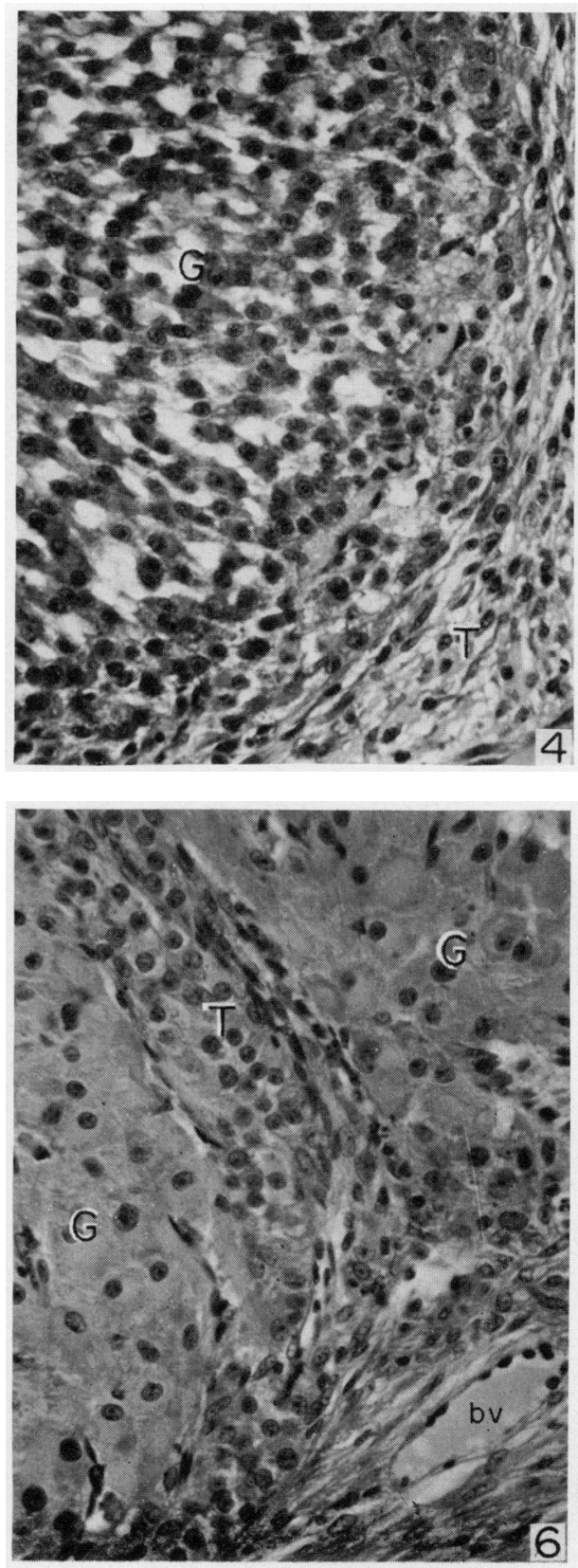
oestrogen during the early follicular phase suppresses the secretion of FSH and LH (Vaitukaitis et al., 1971; Tsai \& Yen, 1971) and the follicular phase is extended beyond its usual length of 14 days, indicating that follicular development has been inhibited.

Progesterone alone has little if any effect on the secretion of FSH or LH in women (Franchimont, 1971), rhesus monkeys (Knobil, 1974), or ewes (Pelletier \& Signoret, 1970; Scaramuzzi et al., 1971). Low doses seem to facilitate the action of oestradiol on positive and negative feedback (see Rothchild, 1965 for review). Larger amounts, such as those secreted by the CL, inhibit the positive feedback of oestradiol but enhance its negative feedback (Knobil, 1974).

\section{During the luteal phase}

The inhibitory influence of progesterone on the positive feedback of oestradiol is important in preventing peaks of LH discharge (and possible ovulation) occurring in the luteal phase in sheep and women (Text-fig. 1). In women the secretion of oestradiol plus progesterone from the CL suppresses the release of gonadotrophins, and thus the CL has direct control over the amount of gonadotrophins reaching it and effectively removes the control of gonadotrophin from the follicles. The number of follicles developing normally is minimal during the mid-luteal phase when FSH and LH are at their lowest. It is not until the CL regresses that the concentration of gonadotrophins is sufficiently high to initiate the development of a new 'wave' of Graafian follicles which require a full 14 days to proceed to preovulatory maturity.

In contrast, because the sheep CL does not secrete oestradiol, oestradiol secretion at any stage of the cycle is an index of follicular activity, i.e. oestradiol has direct access to the hypothalamic-pituitary feedback system, the negative loop of which continues to operate via the follicle throughout the luteal phase. The secretion of progesterone by the CL only modifies this system by inhibiting the positive feedback of oestradiol at the cyclic centre. Because progesterone has

\section{PLATE 2}

Fig. 3. Graafian follicle (diameter $10-20 \mathrm{~mm}$ ) from the right ovary of a woman at the time of ovulation on Day 11. Mean cycle length $=28$ days. Endometrium: late proliferative. Concentration of $\mathrm{OE}_{2}$ in follicular fluid $=82 \mathrm{ng} / \mathrm{ml}$, in peripheral plasma $=0.085$ $\mathrm{ng} / \mathrm{ml}$, in ovarian venous plasma $=1 \cdot 16 \mathrm{ng} / \mathrm{ml}$. The excretion of total oestrogen had fallen to $12 \mu \mathrm{g} / 24 \mathrm{hr}$ from a peak of $61 \mu \mathrm{g} / 24 \mathrm{hr} 2$ days before operation. The granulosa cells (G) have dissociated and the cytoplasm of the thecal cells $(T)$ is much less abundant (compare with Fig. 2). $\times 180$.

FIG. 4. A recently ruptured Graafian follicle from the left ovary of the same subject as in Fig. 3. The concentration of $\mathrm{OE}_{2}$ in ovarian venous plasma $=0.69 \mathrm{ng} / \mathrm{ml}$. The histological appearances of granulosa $(G)$ and thecal $(T)$ cells are similar to those in Fig. $3 . \times 180$.

FIg. 5. Corpus luteum from right ovary of a woman on Day 14. Mean cycle length $=28$ days. Endometrium: early secretory. Concentration of $\mathrm{OE}_{2}$ in fluid aspirated from $\mathrm{CL}=14 \mathrm{ng} / \mathrm{ml}$, in ovarian venous plasma $=8.23 \mathrm{ng} / \mathrm{ml}$, in peripheral plasma $=$ $0.198 \mathrm{ng} / \mathrm{ml}$. The cytoplasm of the granulosa cells $(\mathrm{G})$ is much greater than at ovulation (compare Figs 3 and 4 ). The thecal cells $(T)$ are smaller but still clearly distinct from the granulosa cells. bv $=$ blood vessel. $\times 180$

Frg. 6. Corpus luteum from the left ovary of a woman on Day 20. Mean cycle length = 31 days. Endometrium: mid-secretory. Concentration of $\mathrm{OE}_{2}$ in ovarian venous plasma $=$ $10.59 \mathrm{ng} / \mathrm{ml}$, in peripheral plasma $=0.29 \mathrm{ng} / \mathrm{ml} ; \mathrm{P}_{4}$ in peripheral plasma $=8 \mathrm{ng} / \mathrm{ml}$. Thecal cells $(T)$ are seen in strands of tissue between the granulosa cells $(G)$ which have fully luteinized. $\mathrm{bv}=$ blood vessel. $\times 180$. 
little if any effect on negative feedback, the CL has no direct control of pituitary gonadotrophins through its own secretions. The lack of fine control of negative feedback by the CL is reflected by its relative insensitivity to acute changes in LH concentration (Short, 1964; Collett et al., 1973) and suggests that because of this 'open-ended loop' the secretion of progesterone is limited by the biosynthetic capacity of the lutein cells. The life-span of the CL in the ewe is dependent on an additional closed loop via the uterus which has a relatively long time-constant. The secretion of progesterone by the CL is responsible for priming the uterus to enable it to produce luteolytic amounts of PGF-2 $\alpha$ (McCracken et al., 1971).

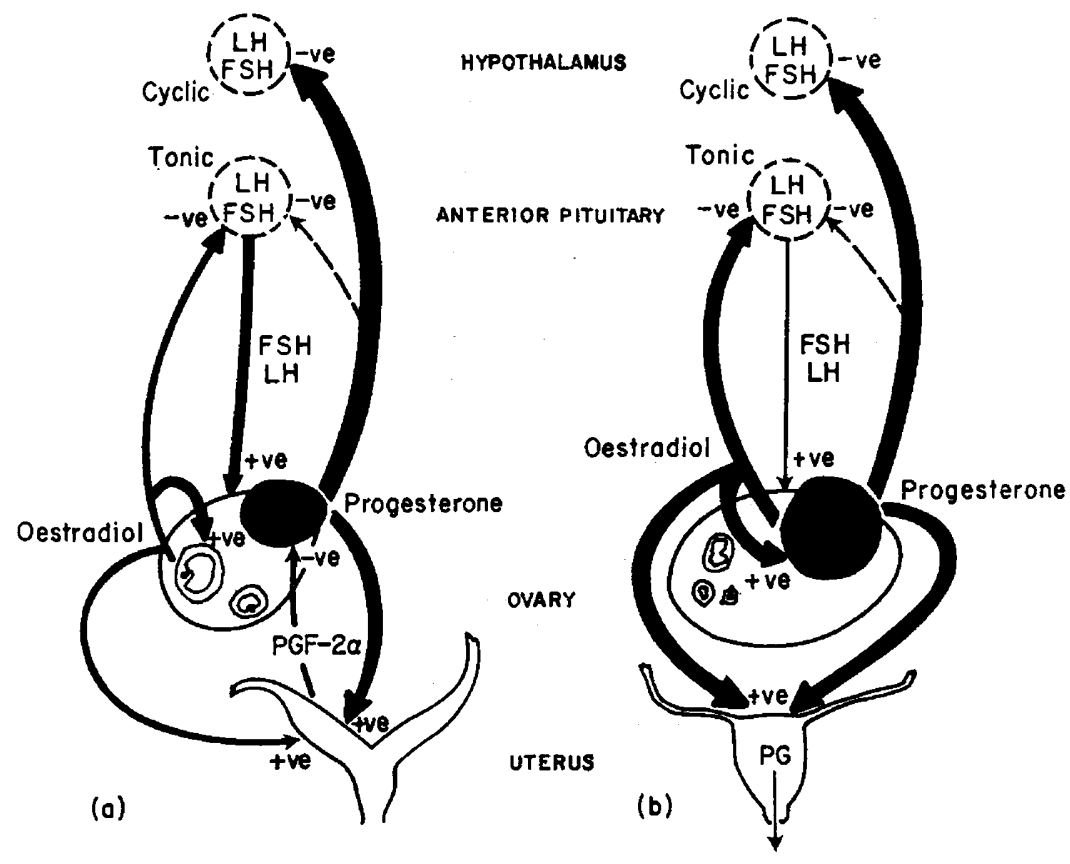

\begin{abstract}
TExT-FIG. 1. Suggested hypothalamic-pituitary-ovarian relationships in the luteal phase of the ovarian cycle in (a) sheep and (b) women. The magnitude of the effect is related to the thickness of the line. In both sheep and women the positive feedback effect of oestradiol is inhibited by the secretion of progesterone from the GL. The human CL controls the basal secretion of gonadotrophins through the negative feedback of oestradiol at the tonic centre and any developing follicles become atretic. In the sheep the CL does not secrete oestradiol. The basal secretion of gonadotrophins is controlled by the negative feedback of oestradiol secreted by the follicles which continue to develop throughout the luteal phase. The life-span of the CL in the ewe depends on an additional negativefeedback loop involving the production of prostaglandin F-2 $\alpha$ from the uterus.
\end{abstract}

In the sheep, follicular development continues unaltered throughout the luteal phase with follicles reaching a diameter of about $5 \mathrm{~mm}$ before becoming atretic. Because the negative feedback originates from the follicle, the secretion of gonadotrophins can never be inhibited to such a degree that follicular growth stops. When luteal regression occurs either spontaneously, by surgical enucleation (Mallampati \& Casida, 1970), or by administration of PGF-2 $\alpha$ (McCracken et al., 1971), there is always at least one follicle ready to proceed rapidly 
through the final stages of follicular maturation. With the fall of progesterone, oestradiol from the preovulatory follicle is able to elicit positive feedback and an ovulatory discharge of LH occurs. This continual follicular development throughout the luteal phase effectively shortens the follicular phase; if it was of the same length as in the human, the ewe would never show oestrous behaviour because of a lack of progesterone priming (Robinson, 1959).

In sheep, the administration of exogenous oestradiol, but not progesterone, for 20 days from Day 4 of the cycle prolongs the life-span of the CL and inhibits follicular development (Piper \& Foote, 1968). When the treatment is stopped luteal regression occurs rapidly but the subsequent ovulation may be delayed for up to 3 weeks. These data suggest that when extrafollicular oestrogen is added to the secretion of progesterone by the CL, LH and FSH are suppressed and the pool of developing follicles reaching the final stages of growth becomes depleted. After cessation of oestrogen treatment, gonadotrophins are presumably released from the pituitary and stimulate the development of a new crop of follicles which, like those in women, require 10-14 days to reach preovulatory maturity.

\section{ACKNOWLEDGMENTS}

We are grateful to Dr W. M. Hunter of the M.R.C. Radioimmunoassay Team for the assays of gonadotrophin, and to the Population Council (T.G.B.) for financial assistance. One of us (K.P.McN.) is a New Zealand N.R.A.G. Fellow.

\section{REFERENCES}

BAIRD, D.T. \& FRASER, I.S. (1974) Blood production and ovarian secretion rates of oestradiol-17 $\beta$ and oestrone in women throughout the menstrual cycle. F. clin. Endocr. Metab. 38, 1009-1017.

BAIRD, D.T. \& FRASER, I.S. (1975) Concentration of oestrone and oestradiol-17 $\beta$ in follicular fluid and ovarian venous blood of women. Clin. Endocr. 4, 259-266.

BAird, D.T., MCGracken, J.A. \& Goding, J.R. (1973) Studies in steroid synthesis and secretion with the autotransplanted sheep ovary and adrenal. In The Endocrinology of Pregnancy and Parturition, pp. 5-16 Ed. C. H. Pierrepoint. Alpha Omega Alpha Publishing Co., Cardiff.

BLOCK, E. (1951) Quantitative morphological investigation of the follicular system in women. Acta endocr., Copenh. 8, 53-54.

BRAND, A. \& DE JONG, W.H.R. (1973) Qualitative and quantitative micromorphological investigations of the tertiary follicle population during the oestrous cycle in sheep. F. Reprod. Fert. 33, 431-439.

Brown, J.B. (1971) Assessment of ovarian function by oestrogen and pregnanediol analysis. In Control of Gonadal Steroid Secretion, pp. 127-141. Eds D. T. Baird \& J. A. Strong. Edinburgh University Press.

Cargille, G.M., Vaitukatris, J.L., Bermudez, J.A. \& Ross, G.T. (1973) A differential effect of ethinyl oestradiol on plasma FSH and LH relating to time of administration in the menstrual cycle. F. clin. Endocr. Metab. 36, 87-94.

Cole, H.H. \& Gupps, P.T. (1969) Reproduction in Domestic Animals. Academic Press, New York.

ColletT, R.A., LAND, R.B. \& Baird, D.T. (1973) The pattern of progesterone secretion by the autotransplanted ovary of the ewe in response to ovine luteinizing hormone. F. Endocr. 56, 401-403.

Collins, D.C., Graham, C.E. \& PREedY, J.R.K. (1973) Urinary levels of oestrogens, pregnanediol and androsterone during the menstrual cycle of the orang utan. Biol. Reprod. 9, 107, Abstr.

Corner, G.W., JR (1956) The histological dating of the human corpus luteum. Am. J. Anat. 98, 377401.

Grisp, T.M., Dessouky, D.A. \& Denys, F.R. (1970) The fine structure of the human corpus luteum of early pregnancy and during the progestational phase of the menstrual cycle. Am. F. Anat. 127, 3770.

DE Jong, F.H., BAird, D.T. \& VAN DER MOLEN, H.J. (1974) Ovarian secretion rates of oestrogens, androgens and progesterone in normal women and in women with persistent ovarian follicles. Acta endocr., Copenh. 77, 575-587. 
Delforge, J.P., Thomas, K., Roux, F., Carneiro de Siqueira, J. \& Ferin, J. (1972) Time relationships between granulosa cell growth and luteinization, and plasma luteinizing hormone discharge in human. 1. A morphometric analysis. Fert. Steril. 23, 1-11.

Franchimont, P. (1971) The regulation of follicle stimulating hormone and luteinizing hormone secretion in humans. In Frontiers in Neuroendrocrinology, pp. 331-358. Eds L. Martini \& W. F. Ganong. Oxford University Press, New York.

Friedrich, F., Breitenecker, G., Sulzer, H. \& Holzner, J.H. (1974) The progesterone content of the fluid and the activity of the steroid $3 \beta$-ol-dehydrogenase within the wall of ovarian follicles. Acta endocr., Copenh. 76, 343-352.

Goldenberg, R.L., Vaitukaitus, J.L. \& Ross, G.T. (1972) Oestrogen and follicle stimulating hormone interactions on follicle growth in rats. Endocrinology 90, 1492-1498.

Graham, C.E., Collins, D.C., Robinson, H. \& Preedy, J.R.K. (1972) Urinary levels of oestrogens and pregnanediol and plasma levels of progesterone during the menstrual cycle of the chimpanzee: relationship to the sexual swelling. Endocrinology 91, 13-24.

Hansel, W., Concannon, P.W. \& Lukaszewska, J.H. (1973) Corpora lutea of the large domestic animals. Biol. Reprod. 8, 222-245.

L'Hermite, M., Niswender, G.D., Reichert, L.E., Jr \& Midgley, A.R. (1972) Serum follicle stimulating hormone in sheep as measured by radioimmunoassay. Biol. Reprod. 6, 325-332.

Hertig, A.G. (1967) Morphological determinants of placentation. In Fetal Homeostasis, Vol. 2, p. 98. Ed. R. M. Wynn. New York Academy of Sciences, New York.

Johansson, E.D.B. \& Wide, L. (1969) Periovulatory levels of plasma progesterone and luteinizing hormone in women. Acta endocr., Copenh. 62, 82-88.

Kaltenbach, C.C., Cook, B., Niswender, G.D. \& Nalbandov, A.V. (1967) Effect of pituitary hormones on progesterone synthesis by ovine luteal tissue. Endocrinology 81, 1407-1409.

KNoвıL, E. (1974) On the control of gonadotrophin secretion in the rhesus monkey. Recent Prog. Horm. Res. 30, 1-36.

Koering, M.J. (1969) Cyclic changes in ovarian morphology during the menstrual cycle in Macaca mulatta. Am. F. Anat. 126, 73-101.

McGracken, J.A., Baird, D.T. \& Goding, J.R. (1971) Factors affecting the secretion of steroids from the transplanted ovary in the sheep. Recent Prog. Horm. Res. 27, 537-582.

MaNatty, K.P., Hunter, W.M., McNeilly, A.S. \& Sawers, R.S. (1975) Changes in the concentrations of pituitary and steroid hormones in the follicular fluid of human Graafian follicles throughout the menstrual cycle. J. Endocr. 64, 555-571.

Mallampati, R.S. \& CAsida, L.E. (1970) Ovarian compensatory hypertrophy following unilateral ovariectomy during the breeding season in the ewe. Biol. Reprod. 3, 43-46.

Mauleon, P. (1969) Oogenesis and folliculogenesis. In Reproduction in Domestic Animals, 2nd edn., pp. 187-215. Eds H. H. Cole \& P. T. Cupps. Academic Press, New York.

Midgley, A.R., JR \& JAFFE, R. (1968) Regulation of human gonadotrophins. IV. Correlation of serum concentrations of follicle stimulating and luteinizing hormones during the menstrual cycle. 7 . clin. Endocr. Metab. 28, 1699-1703.

Mrkhail, G. (1970) Hormone secretion by the human ovaries. Gynaecol. Invest. 1, 5-20.

Niswender, G.D. \& SpIEs, H.G. (1973) Serum levels of luteinizing hormone, follicle stimulating hormone and progesterone throughout the menstrual cycle of rhesus monkeys. 7 . clin. Endocr. Metab. 37, 326-328.

Pedersen, T. (1970) Follicle kinetics in the ovary of the cyclic mouse. Acta endocr., Copenh. 64, 304-323.

Pedersen, T. (1972) Follicle growth in the mouse ovary. In Oogenesis, pp. 361-376. Eds J. D. Biggers \& A. W. Schuetz. University Park Press, Baltimore.

Pelletier, J. \& Signoret, J.P. (1970) Influences respectives de l'oestradiol et de la progesterone sur la décharge de LH dans le sang chez la Brebis castrée. In L'Inhibition de l'Ovulation, pp. 215-225. Masson, Paris.

Piper, E.L. \& Foote, W.C. (1968) Ovulation and corpus luteum maintenance in ewes treated with $17 \beta$-oestradiol. 7. Reprod. Fert. 16, 253-259.

RAJAKoski, E. (1960) The ovarian follicular system in sexually mature heifers with special reference to seasonal, cyclic and left-right variations. Acta endocr., Copenh., Suppl. 52.

Robinson, T.J. (1959) The oestrous cycle of the ewe and doe. In Reproduction in Domestic Animals, pp. 291-333. Eds H. H. Cole \& P. T. Cupps. Academic Press, New York.

Ross, G.T., Cargille, C.M., Lipsett, M.B., Rayford, P.L., Marshall, J.R., Strott, C.A. \& Rodbard, D. (1970) Pituitary and gonadal hormones in women during spontaneous and induced ovulatory cycles. Recent Prog. Horm. Res. 26, 1-62.

Rothсінд, I. (1965) Interrelations between progesterone and the ovary, pituitary and C.N.S. in the control of ovulation and regulation of progesterone secretion. Vitams Horm. 23, 209-305.

Ryan, K.J. \& SmITH, O.W. (1965) Biogenesis of steroid hormones in the human ovary. Recent Prog. Horm. Res. 21, 367-403. 
Sanyat, K.M., Berger, M.J., Thompson, I.E., Taymor, M.L. \& Horne, H.W. (1974) Development of Graafian follicles in adult human ovary. I. Correlation of oestrogen and progesterone concentration in antral fluid with growth of follicles. F. clin. Endocr. Metab. 38, 828-835.

Savard, K., Marsh, J.M. \& Rice, B.F. (1965) Gonadotrophins and ovarian steroidogenesis. Recent Prog. Horm. Res. 21, 285-365.

Scaramuzzi, R.J., GaldWEll, B.V. \& MooR, R.M. (1970) Radioimmunoassay of LH and estrogen during the estrous cycle of the ewe. Biol. Reprod. 3, 110-119.

Scaramuzzi, R.J., Tillson, S.A., Thorneycroft, I.H. \& Caldwell, B.V. (1971) Action of exogenous progesterone and estrogen on behavioural estrus and luteinizing hormone levels in the ovariectomized ewe. Endocrinology 88, 1184-1189.

SHORr, R.V. (1964) Ovarian steroid synthesis and secretion in vivo. Recent Prog. Horm. Res. 20, 303-340.

Smeaton, T.G. \& Robertson, H.A. (1971) Studies on the growth and atresia of Graafian follicles in the ovary of the sheep. F. Reprod. Fert. 25, 243-252.

Stevens, V.C., Sparks, S.J. \& Powell, J.E. (1970) Levels of oestrogens, progestogens and luteinizing hormone during the menstrual cycle of the baboon. Endocrinology 87, 658-666.

TsAI, C.C. \& YEN, S.S.C. (1971) The effect of ethinyl oestradiol administration during early follicular phase of the cycle on the gonadotrophin levels and ovarian function. F. clin. Endocr. Metab. 33, 917-923.

Vartukaitis, J.L., Bermudez, J.A., Gargille, C.M., Lipsett, M.B. \& Ross, G.T. (1971) New evidence for an anti-oestrogenic action of clomiphene citrate in women. 7. clin. Endocr. Metab. 32, 503-508.

YoungLai, E.V. \& Short, R.V. (1970) Pathways of steroid biosynthesis in the intact Graafian follicle of mares in oestrus. F. Endocr. 47, 321-333.

Yussman, M.A. \& TAYMOR, M.L. (1970) Serum levels of follicle stimulating and luteinizing hormone and plasma progesterone related to ovulation by corpus luteum biopsy. F. clin. Endocr. Metab. 30, 396-399. 